\title{
Örgütsel Adaletin Örgütsel Sinizm ve İşten Ayrılma Niyetine Etkisi: Otel İşletmeleri Araştırması
}

\author{
Berrin GÜZEL* Gökhan AYAZLAR** \\ * Adnan Menderes Üniversitesi, Didim Meslek Yüksekokulu, Didim/AYDIN. \\ ** Muğla Sıtkı Koçman Üniversitesi, Turizm İşletmeciliği ve Otelcilik Yüksekokulu, MUĞLA.
}

\begin{abstract}
Özet
Çalışmada örgütsel adalet algısının otel çalışanlarında örgütsel sinizm algılarına ve işten ayrılma niyetine etkileri araştırılmıştır. Didim bölgesindeki dört ve beş yıldızlı otel işletmeleri çalışmanın evreni olarak tanımlanmış, buna göre de 218 anket elde edilmiştir. Analizler sonucunda örgütsel adalet sinizmi ve işten ayrılma niyetini negatif yönde etkilemektedir. Sinizmin duygusal boyutu dağıtım ve etkileşim adaletinden negatif yönde etkilenirken; davranış boyutu dağıtım ve etkileşim adaletinden negatif, işlemsel adaletten ise pozitif yönde etkilenmektedir. İşten ayrılma niyeti ise sadece işlemsel adaletten etkilenmektedir ve negatif yönlüdür.
\end{abstract}

Anahtar Kelimeler: örgütsel adalet, örgütsel sinizm, otel ișletmeleri, ișten ayrılma niyeti.

\section{The Effect of Organizational Justice Towards Organizational Cynicism and Job Quit Intentions: A Research on Hotels}

\begin{abstract}
The present study aims to explain the effect of organizational justice towards organizational cynicism and job quit intentions of hotel employees. Four and five star hotels in Didim is selected as the sample of the study and 218 questionnaires are obtained. According to the results, organizational justice affects organizational cynicism and job quit intention negatively. While, the affective dimension of cynicism is afected by distributive and interactional justice negatively; the behavioral dimension is negatively affected by distributive and interactional justice, and positively affected by procedural justice. Besides, only procedural justice affects job quit intention and it is negative.
\end{abstract}

Keywords: organizational justice, organizational cynicism, hotels, job quit intention.

\section{GíRis}

Örgütsel adalet çalışmaları, kişilerin iş ortamındaki adaleti ne şekilde algıladıkları ve bunun tutum ve davranışlarını ne şekilde etkilediğine yöneliktir (Colquitt,2009: 73). Nitekim kişilerin işyerinde uzun süre harcaması ve sürekli gündemlerinde olması nedeniyle insanlar adalet konusunda oldukça hassastır (Greenberg,2004:359). İşyerinde kişiler kendilerine adaletsiz davranıldığına inandığında, bu duruma olumsuz şekilde tepki vermekte (Greenberg,2011:72), tatmin olmamakta ve kendi adalet duyguları çerçevesinde adaletsizliği ortadan kaldırıcı davranışlarda bulunmaktadır (Stroh vd.,2002:78).

Mevcut çalışmanın amacı, emek-yoğun otel işletmelerinde çalışanlarda örgütsel adalet algısının örgütsel sinizme ve işten ayrılma niyetine doğrudan etkilerini ortaya koymaktır.

\section{Literatür Özeti}

\section{1. Örgütsel Adalet}

Çalışanlar çoğunlukla örgütten elde ettiklerini ve kendilerine yönelik davranışın adaleti ile ilgilenmektedir (Williams vd.,2002:34). Bu anlamda örgütsel adalet, örgüt tarafından kendilerine adil şekilde davranıldığına dair bakış açılarını ifade etmektedir (Blakely vd.,2005:261). Örgütsel adalet, kişi odaklı olmasına rağmen, sosyal bir bileşeni de içermektedir. Temel motivasyon kaynağ 1 kişinin kendini başkaları ile kıyaslaması iken, diğer çalışanlar ile standartların ortaya konulması şekline dönüşmüştür (Greenberg ve Baron,2003:201). Buna göre, örgütsel adalet teorisi, örgütte çıktıların çalışanlara dağıtımında adil prosedürlerin kullanılacağına ve yöneticilerinin kendilerine adil davranmadığını algıladıklarında çalışanların örgüte katkı sağlamayacağını açıklamaktadır (George ve Jones, 2008:197).

Adalet ile ilgili deneyimdeki olumsuzluk, kişinin adalet duygusunun ihlal edilmesi noktasında başlamaktadır. Ancak örgütsel adaletsizliğin türleri, karmaşıklığı ve boyutları tam olarak belirgin değildir. yapılan çalışmalar türlerini açıklasa da, boyut veya sıklığını açıklamamaktadır. Diğer yandan adil olan ile daha adil olan arasındaki ince ayrım da belirsizdir. "Daha adil" kavramı, ihlallerin düzeltilmesinde ortaya çıkmaktadır (Gilliland,2008:274).

Her ne kadar kişi kendini birçok durum karşısında adil olarak algılasa da, adil olmak birçok farklı davranış biçimini de 
beraberinde getirmektedir. Bu anlamda adalet, kararların nasıl alındığından, yöneticilerin nasıl davrandığına kadar birçok farklı konuda ele alınmakta, bu da örgütsel davranış kapsamında adaleti farklı boyutlara ayırmaktadır (Greenberg,2011:68-74). Bu anlamda örgütsel adaletin dağıtım, işlemsel, etkileşim ve bilgi olmak üzere bir takım bileşenleri bulunmaktadır (Blakely vd.,2005:261).

Dă̆ıtım adaletinin yaygın hedefi, azami verimliliğin sağlanması olduğundan (Colquitt,2001:389), kişinin örgüt içerisinde çalışmasının maliyeti ile elde ettiği faydaların kıyaslanmasına dayanmaktadır. Eşitlik teorisi ise, işyerindeki kişilerarası eşitliğin önemini vurgulamaktadır (Kitchin,2010:74). Bu anlamda dağıtım adaleti, dağıtılan ödüllerin miktarına değil, çalışanlar arasında dağıtımın eşitliğine yöneliktir (Mitchell vd.,2012:731). Ancak dağıtım adaleti konusunda yanıltıcı nokta, kaynakların dağıtım için uygun standartlarının belirsizlik içerisinde olmasıdır (Greenberg,2004:360).

Işlemsel adalet, ödüllerin belirlenmesinde kullanılan prosedürlerin adaletine yönelik algılar olarak tanımlanmaktadır. Çalışanlar örgüt içerisindeki prosedürlerin, örgütün "doğru işe" bağlılığını göstermesi nedeniyle oldukça hassastır. Bu anlamda prosedürlerin adil algılanması, çalışanların örgüte güvenini de arttıracaktır (Greenberg,2004:354). Ancak çalışanlar işlemsel adalet kapsamında, karar almada söz hakkı, kuralların uygulanmasında istikrar, bilginin doğruluğu, hataları düzeltme olanağı gibi farklı kriterleri dikkate almaktadır (Greenberg,2011:69). Bu kriterlerle işlemsel adalet, sadece bir süreç kontrolü olarak kalmamakta, örgütsel düzenlemeler gibi yasal olmayan kavramları da içermektedir (Colquitt vd.,2001: 426). Böylece, işlemsel adaletteki bu yapısal özellikler, dağıtım sürecindeki bireysel farklılıkları ortadan kaldırmaktadır (Aryee vd.,2004:3). İşlemsel adalet çıtıların mevcut dağılımına yönelik değildir. $\mathrm{Bu}$ anlamda işlemsel adalet prosedürlerin ne kadar adil olduğundan ziyade, ne kadar adil algılandığına dair çalışanların tepkilerine dayanmaktadır. $\mathrm{Bu}$ yüzden eşitlik teorisinde olduğu gibi, çalışanların algıları oldukça önemlidir. (George ve Jones,2008:197).

Özellikle işlemsel adaletteki sorunlar, çalışanların örgüt ile ilişkilerini, sosyal değişimden ekonomik değişime dönüştürmekte; çalışanı da karşılıklı güven ilişkisinden vazgeçerek, sadece gerekenleri yapmaya yönelmektedir (Williams vd.,2002:34). Bu nedenle işlemsel adalet, hem örgütün hem de çalışanların fayda sağlayacak olması nedeniyle ayrıca öneme sahiptir (Greenberg ve Baron 2003:204).

Etkileşim adaleti kimi çalışmalarda işlemsel adaletin alt boyutu olarak kimi çalışmalarda ise üçüncü boyut olarak tanımlanmaktadır (Colquitt,2001:386). Etkileşim adaleti, etkileşim konusunun bileşeni olarak iletişimi içerdiğinden (Karriker ve Williams,2009: 115), kişilerarası iletişimin adaleti ile ilişkili olup, prosedürler ile uygulamalar arasındaki farklılığı ortaya koymaktadır (Greenberg,2004:357). Yöneticilerin çalışanlarıyla olan kişilerarası ilişkilerinde, bu ilişkinin kalitesinin de önemli olduğu göz önüne alındığında (Greenberg ve Baron,2003:205), çalışanlara açıklama yapılması, çalışanın örgüt için önemli olduğunu ve açıklama yapılmaya değer bulunduğu mesajını iletmektedir. Nitekim bu tür davranışların sadece sembolik değeri bile, kişinin kararları kabul etmesinde oldukça etkilidir (Greenberg,2004:361).

\section{2. Örgütsel Sinizm}

Herhangi bir işletmedeki çalışanlar gözlemlendiğinde örgütsel yapı ve onun yönetimiyle ilgili sinik davranışlar gösteren çalışanlarla karşılaşılması çok güçlü bir ihtimaldir. Bu davranışları onların yönetimin yetersizliğiyle ilgili şakalarındaki sözlü davranışlarında, küçümseyerek gülmeleri ve alaycı bakışları gibi sözsüz davranışlarında ve kapılarına imalı karikatürler yapıştırmak gibi diğer davranışlarında görmek mümkündür (Fitzgerald,2002:5). Neredeyse tüm örgütlerde sinik davranışlara sahip çalışanların yer alması, son yıllarda sinizmin örgütsel boyutta yoğun olarak ele alınmasına öncülük etmiştir (James,2005:6). Örgütsel sinizm, doğrudan bireylere veya işletmenin bütününe yönelik olarak, işyerindeki yetkilerle geliştirilen olumsuz tutumlar olarak tanımlanmaktadır (Reichers vd., 1997:50). Ayrica kavram istihdam edilen çalışanın işletme değerlerini, faaliyetlerini ve motive edici özelliklerini eleştirel değerlendirmesi sonucundaki tutumu olarak tanımlanmaktadır (Bedeian, 2007:11). Bu tutum örgütün tamamına karşı olabileceği gibi bir bölümüne karşı da olabilir (Naus vd., 2007:689).

Dean vd. (1998:345) tanımlarda vurgulanan bu olumsuz tutumların üç boyut içerdiğini belirtir; (1) örgütün bütünlükten yoksun olduğuna olan inanç, (2) örgüte yönelik olumsuz duyuşsal etki ve (3) bu inanç ve etkiye uygun olarak örgüte yönelik aşağılayıcı ve eleştirici davranışlar geliştirme eğilimidir. Örgütsel sinizmle ilgi yapılan araştırmaların çoğunda kabul gören ve uygulanan bu boyutlar duyuşsal, bilişsel ve davranışsal olarak isimlendirilmekte ve sinizm ölçümünde sıklıkla kullanılmaktadır. Fitzgerald'a (2002:19) göre duyuşsal boyut temel insan duygularının negatif yönünü, bilişsel boyut örgütsel anlamdaki bütünlük ve samimiyetin bilinç düzeyindeki değerlendirilmesini, davranış boyutu ise örgütsel sinizm kapsamında geliştirilen eleştirel ve küçümseyici davranışları nitelendirmektedir.

Çalışanlar arasında görülen sinizm belirtilerinde öncelikli olarak çalışanlarla ilgili bir seçim söz konusu olduğunda nasıl yapıldığıyla ilgili belirsizlik, işletmede yürütülen programlara ve program hazırlayıcılarına karşı duyulan güven eksikliği, aynı konumda çalışanlar arasındaki güç eşitsizliği algısı ve hedeflere ait inançlarda azalma (Kelly ve Kelly, 1991:44) nedenleri yer almaktadır. Benzer biçimde fazla işgücü ve karşılanmayan vaatler (Cordes ve Dougherty, 1993:623), yönetici desteğindeki azalma ve ikiyüzlülük (Johnson ve O'Leary Kelly, 2003:630) ve işyerinde azalan olanaklar (Naus vd., 2007:695) da örgütsel sinizmin öncülleri olarak gösterilmektedirler.

Abraham (2000:269) ve Andersson (1996:1397) çalışanlara ait olumsuz çıktıların ana nedeni olarak örgütsel sinizmi göstermektedir. Önceki araştırmalarda örgütsel sinizmin çalışanların çoğunda görüldüğü ve işletmeler açısından istenmeyen pek çok sonuçları olduğu belirtilmektedir. Örgütlerde çalışan tutumlarına yansıyan bu sonuçlara örnek olarak düşük performans, düşük moral, yüksek devamsızlık (Abraham,2000:273), işten ayrılma niyeti (Cordes ve Dougherty,1993:623), hayal kırıklığ (Andersson,1996:1398), güven duygusunda azalma (Johnson ve O'Leary Kelly,2003:643), örgütsel vatandaşlık davranışlarında azalma (Hochwarter vd.,2004:53) ve işe yabancılaşma (Abraham, 2000:269) gösterilmektedir. 


\section{3. İșten Ayrılma Niyeti}

Örgütsel davranış alanında yaygın şekilde çalışılan konulardan biri olan işten ayrılma davranışı (Hammerbergi, 2002: 7) temelinde işten ayrılma niyeti; düşünme, planlama ve işten ayrılmayı isteme şeklinde sıralanan bilişsel bir süreçtir (Lambert, 2006: 59). İşten ayrılma niyetinde, çalışanın niyetinin işe son verme davranışına dönüşmesi belirli bir süreç dahilinde gelişmekte ve bu süreç birçok değişkene bağlı olarak gelişmektedir (Hom vd., 1992; 905). Mobley vd. (1977) işten ayrılma niyetine yönelik bu süreci geliştirdiği beş aşamalı modelde açıklamaktadır. Bu model (Şekil 1) çalışanın mevcut işini değerlendirmesi ve tatminsizlik duygusu ile tanımlanması kişinin işten çıkma düşüncesini ortaya çıkarmakta, bu da olası iş alternatiflerinin beklenen faydasını ve işten çıkmanın maliyetinin hesaplanmasına, bu da işten ayrılma veya işte kalma kararına ve son olarak işten ayrılmaya kadar bir süreci kapsamaktadır.

\section{Şekil 1: Mobley vd. (1977) İşten Ayrılma Niyeti Modeli}

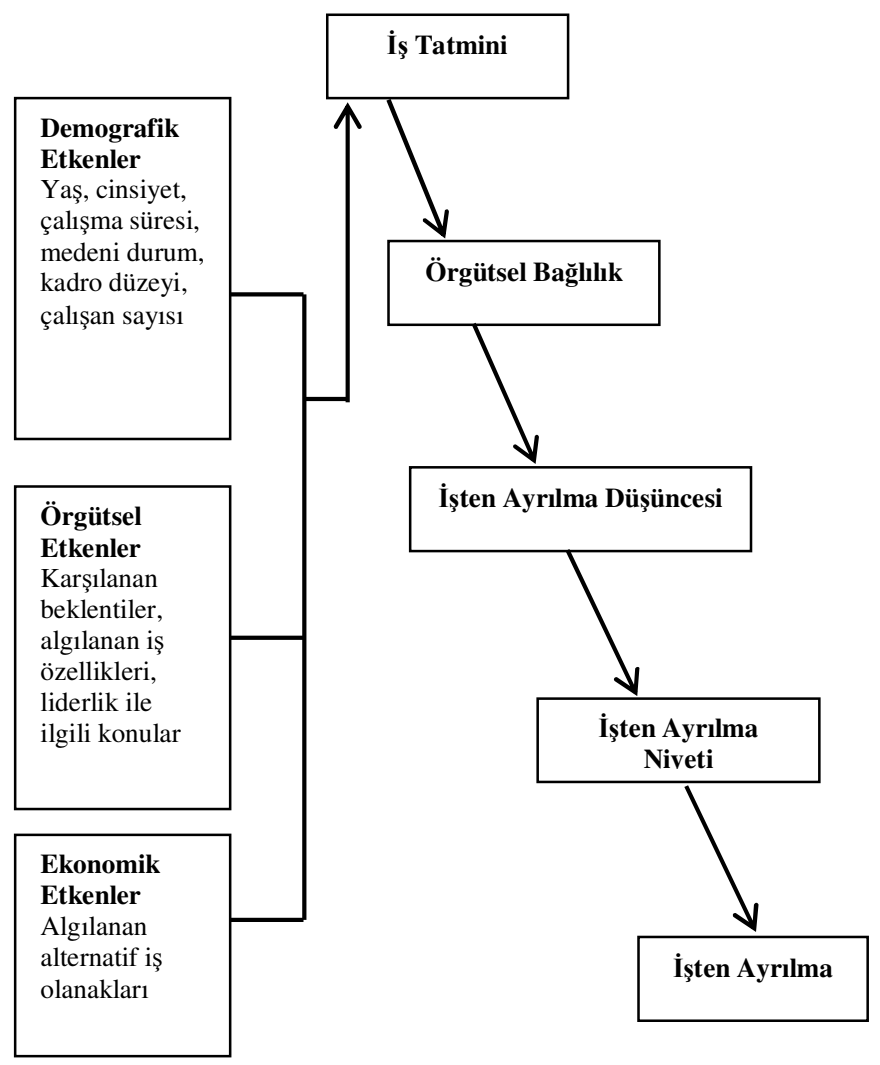

Kaynak: You, Young Jae,(1996). An Empirical Test of Turnover Theory: In the case of Korean Hotel Employees, Asia Pacific Journal of Tourism Research, 1(1), 56.
Bu modelin önemli bir özelliği ise önceki çalışmalar gibi iş tatmini ve işten ayrılma arasındaki doğrudan ilişkilere yönelmemekte, tatminsizlik deneyimi ile işten ayrılma davranışı arasında gerçekleşebilecek olan bilişsel ve davranışsal olguları belirtmektedir. Bu noktada işten ayrılma niyeti, işten ayrılma davranışının bir önceki aşaması olarak da tanımlanmaktadır (You, 1992: 51).

Bireylerin örgütten ayrılma ya da örgütte kalma kararında oldukça etkili olan etkenlerden biri iş tatminidir (Shaw, 1999; Trevor, 2001; Morrison, 2004; Coomber ve Barriball, 2007; Korunka vd., 2008; Ohana ve Meyer, 2010; Mahdi vd., 2012; Ucho vd., 2012). İşgörenlerin bedensel ve zihinsel sağlıkları yanında, ruhsal duygularının belirtisi olan iş tatmini, maddi çıkarlar, iş güvenliği, işin uygunluğu, çalışanın yeteneği, örgütün durumu ve yöneticinin tutumu ile ilişkilidir (Şimşek vd., 2005: 150). Otel işletmeleri için iş tatmininin işten ayrılma niyeti üzerindeki olumsuz etkisi göz önüne alındığında (Jang ve George, 2012: 592), özellikle yorucu iş temposunda, farklı müşterilere hizmet veren otellerde işinden tatmin olamayan bir çalışanın verimli ve uyumlu çalışması mümkün olmamaktadır (Toker, 2007: 94). Diğer yandan ücret düzeyinden duyulan tatminsizlik (Brown vd., 2009; Chan ve Morrison, 2000; Lam vd., 2001; Tzeng, 2002) motivasyon eksikliği (Yıldız vd., 2009) ve performans düşüklüğü (Bridges vd., 2007; Rehman, 2012) ile işten ayrılma niyetinde ve işten ayrılma davranışında artışa neden olmaktadır.

İşten ayrılma niyeti literatürde yaygın şekilde çalışılmış ve çeşitli değişkenler ile ilişkilendirilmiş bir kavramdır. Ayrıca, iş güvencesinin olmaması (Blau, 2007; Hsu vd., 2003), örgütsel bağlilık (Cho vd., 2009; Chen, 2006; Geurts vd., 1999; Rosin ve Korabik, 1995; Sarıdede ve Doyuran, 2004), örgütsel/yönetici desteği (Conklin ve Desselle, 2007; Loi vd., 2006; Allen vd., 2003), işten ayrilma niyetini azaltırken; iş/ortam/mesleki stres (Onay ve Kılc1, 2011; O’Neill ve Davis, 2011; Layne vd., 2004) ve duygusal tükenmişlik (Ducharme vd., 2008; Herda ve Lavelle, 2012; Karatepe ve Aleshinloye, 2009; Korunka vd., 2008) işten ayrılma niyetini arttırmaktadır.

\section{4. Örgütsel Adalet - Örgütsel Sinizm}

Çalışanların çoğunda sinizmin ortaya çıkmasının bazı etkenlerin tetiklenmesiyle mümkün olduğu düşünülmekte ve bu etkenlerin çoğu, işyerinde geliştirilen ilişkiler ve işyeri uygulamalarının nasıl algılandığıyla ilişkilendirilmektedir. Masterson vd. (2000:746) işletmelerde adaletin çalışanların işyerine etkileri ve tepkileri üzerinde önemli bir etkisi olduğuna dair açık göstergeler olduğunu belirtmektedir. Diğer bir ifade ile, çalışanlar kendilerine yüklenen iş yükü, tercih ve ödüllerin adaletli olup olmamasına göre işyerine karşı bir tutum sergilemektedir (Greenberg,1990:399). Çalışanların örgütün kendilerine karşı dürüst davranmadığına dair inanç, çalışanların negatif duygusal tepkilerinin, örgütü eleştirici ve küçümseyici davranışlar aracılığıyla iletilmesine neden olmaktadır (Abraham,2000:272).

Örgütsel adalet ile sinik tutum arasındaki ilişkiye yönelik birtakım çalışmalar yapılmıştır (O'Leary,2003; Kanter ve Mirvis,1991; Fitzgerald,2002; Johnson \& O’Leary-Kelly,2003). Andersson (1996), Bernerth vd. (2007), James (2005) ve Kutanis ve Çetinel (2009) örgütsel adalet ile örgütsel sinizm arasındaki negative yönlü ilişkide, çalışanların örgütsel 
adaletsizlik algılarının, sinik duygularını artırdığını belirtmektedir. Bateman vd. (1992:768) ise adaletsizlik algıs1 olan işletmelerdeki çalışanların daha güvensiz, bıkkın ve kuşkucu olduklarını belirtmiştir. Adalet konusundaki olumsuzluklar, devamsızlık ve çalışan hırsızlığ (Greenberg,1990) gibi işletmeye zarar verici çıtıllara da neden olmaktadır. Çalışanlar adalet algısı oluştururken, genel anlamda bütüncül yaklaşmaktadır. $\mathrm{Bu}$ anlamda adalet algısına dair yaşanan deneyimlerin kaynaklarını ayırabilmelerine rağmen, bir davranışta bulunmada adaletin genel boyutu önemli olmaktadır (Patel vd.,2012:214). Buna göre;

$H_{1 a}:$ Genel adalet algısı, örgütsel sinizmi negatif yönlü etkilemektedir.

Ancak her ne kadar örgütsel adalet boyutları birbirleri ile ilişkili olsa da, çalışanların iş tutumları ile ilişkilerinde bu boyutlar birbirinden farklı sonuçlara neden olmaktadır (DeConinck,2010:1350). Bu kapsamda, adaletin boyutları ile örgütsel sinizm arasındaki ilişkiyi inceleyen çalışmalarda Efeoğlu ve İplik (2011) ve Fitzgerald (2002) adalet ve sinizmin bütün alt boyutları arasında negatif yönlü ilişkiyi incelemiştir. Bernerth vd. (2007) ise sadece dağıtım ve etkileşim adaletinin örgütsel sinizm ile negatif ilişkisini belirtmiştir. Buna göre;

$H_{1 b}:$ Dağıtım adaleti algısı, örgütsel sinizmi inanç, duygusal ve davranış boyutunda negatif yönlü etkilemektedir.

$H_{1 c}$ : İslemsel adalet algısı, örgütsel sinizmi inanç, duygusal ve davranış boyutunda negatif yönlü etkilemektedir.

$H_{l d}$ : Etkileşim adaleti algısı, örgütsel sinizmi inanç, duygusal ve davranış boyutunda negatif yönlü etkilemektedir.

\section{5. Örgütsel Adalet - İşten Ayrılma Niyeti}

Örgütsel adalet kavramı, örgütsel bağlılık ile ilişkilendirildiğinde Folger ve Konovsky (1989) özellikle işlemsel adaletin dikkate alınması gerektiği vurgulamıştır (s.128). Bu noktada Cohen-Charash ve Spector (2001:306) da kavramı örgütsel bağlılık ile ilişkilendirmiş ve her ne kadar adaletin üç boyutu örgütsel bağlılık ile ilişkili olsa da, özellikle işlemsel adaletin duygusal bağlılık ile ilişkisini belirtmiştir. Örgütsel adaletin doğrudan işten ayrılma niyetindeki etkisinde ise Colquitt vd. (2001: 437) kavramlar arasında doğrudan bir ilişki saptamıştır. Bu noktada özellikle dağıtım adaletinin, örgütsel adaletin diğer boyutlarına kıyasla daha baskın olduğunu da belirtmiştir. Kim ve Leung (2007) ise kültürlerarası farklılık olarak kavramları ele almış ve örgütsel adaletin işten ayrılma niyetini etkilediğini belirtmiştir. Buna göre;

$H_{2 a}$ : Genel adalet algısı, işten ayrılma niyetini negatif yönlü etkilemektedir.

$H_{2 b}$ : Dağltım adaleti, işlemsel adalet ve etkileşim adaleti, işten ayrılma niyetini negatif yönlü etkilemektedir.

\section{Materyal ve Yöntem}

Çalışmada örgütsel adalet ölçeği Niehoff ve Moorman (1993) tarafından geliştirilmiş ve toplamda 20 ifadeden oluşmuştur. Örgütsel adalet algısına yönelik ifadelerden bazıları "çalışma saatlerim oldukça adildir", "ücretimin oldukça adil olduğunu düşünüyorum”, "kararlar alınmadan önce müdürüm, tüm çalışanlarının konu ile ilgili sıkıntılarını dinler", "müdürümün aldığı kararlara karşı çıkma hakkımız vardır" ve "işimle ilgili kararlar aldığında, müdürüm benim kişisel ihtiyaçlarıma duyarlı davranır" şeklindedir. Ölçeğin genel güvenilirliğine yönelik Cronbach alpha değeri ,905'tir. Faktör analizleri sonucunda örgütsel adalet algısında dağıtım adaleti, işlemsel adalet ve etkileşim adaleti olmak üzere üç boyut elde edilmiştir. Güvenilirliğe yönelik Cronbach alpha değerleri dağıtım adaletinde ,738; işlemsel adalette ,865 ve etkileşim adaletinde ,891'dir.

Örgütsel sinizm ölçeği Dean, Brandes ve Dharwadkar (1998) tarafından geliştirilen 13 ifadeden oluşmaktadır. Kullanılan ifadelerden bazıları "işletmenin yapacağını söylediği şeyler ile gerçekleşenler arasında çok az benzerlik görüyorum”, "çalıştığım işletmenin sloganları ve uygulamalarıyla dalga geçtiğimi fark ettim", "çalıştığım işletme beni kızdırır" ve "çalıştığım işletmenin söylediğinin başka, uyguladığının başka olduğuna inanıyorum" şeklindedir. Ölçeğin genel güvenilirliğine yönelik Cronbach alpha değeri ,814'tür. Örgütsel sinizm kapsamında duygusal ve davranış olmak üzere iki faktör elde edilmiştir. Bu durumda genel adalet algısı ile adaletin boyutlarının sinizmin inanç boyutuna yönelik $\mathrm{H}_{l b}, \mathrm{H}_{l c}$ ve $\mathrm{H}_{l d}$ kısmen desteklenmiștir. Cronbach alpha değerleri duygusal boyutunda ,817 ve davranış boyutunda ,793'tür.

İşten ayrılma niyetine yönelik ölçek Singh vd. (1996) tarafından oluşturulmuştur ve "gelecek yıl büyük olasılıkla kendime başka bir otelde yeni bir iş arayacağım" ve "gelecek yıl büyük olasılıkla farklı bir sektörde yeni bir iş arayacağım" gibi ifadeler kullanılmıştır. Ölçeğin Cronbach alpha değeri ,823'tür.

Çalışmaya yönelik veriler Didim bölgesinde yer alan dört ve beş yıldızlı otel işletmelerindeki çalışanlardan elde edilmiştir. Çalışmaya yönelik veri toplama tekniği ise anket olarak tercih edilmiştir. Bu sayede kısa zamanda daha fazla veri toplanması sağlanmıştır.

Çalışmaya yönelik veriler Didim bölgesinde yer alan dört ve beş yıldızlı otel işletmelerindeki çalışanlardan elde edilmiştir. Çalışmaya yönelik veri toplama tekniği ise anket olarak tercih edilmiştir. Bu sayede kısa zamanda daha fazla veri toplanması sağlanmıştır. Araştırmada örneklem yöntemi kullanılmıştır. Zira evrenin geniş olması, bu yöntemi zorunlu kılmaktadır (Kağıtçıbaşı, 2010: 65). Burada önemli olan nokta, evreni temsil edecek olan örneklem büyüklüğünün kararının verilmesidir. $\mathrm{Bu}$ anlamda maliyetleri arttırmayacak kadar küçük, evreni temsil edebilecek kadar da büyük olmasınının sağlanması gerekir (Gegez, 2010: 39). Araştırılacak olan kavramların olumsuz olması nedeniyle işletmeler bünyelerinde anket uygulanmasına olumlu bakmamaktadır. $\mathrm{Bu}$ da örneklemin yönteminin tesadüfi olmayan kolayda örnekleme olmasını zorunlu kılmaktadır. Bu sayede sadece ulaşılabilir olan bireyler tercih edilmiştir (Gegez, 2010: 217).

T.C. Kültür ve Turizm Bakanlığı'nın verileri doğrultusunda, çalıșmanın yapıldığ 1 Didim ilçesinde ise işletme belgeli toplam onbir adet otel işletmesi bulunmakta bunların dördü 5 yıldızlı ve ikisi ise 4 yıldızlıdır (www.aydinkultur.gov.tr). Ancak çalışmanın yapıldığı dönem sezon harici olması nedeniyle, dört ve beş yıldızlı otellerden sadece birer tanesi açıktır. Bu nedenle çalışmada bir adet beş ve bir adet dört yıldızlı otel işletmesi 
incelenmiştir. Çalışmada toplam evrenin saptanması için ilgili otellerin yöneticileri ile görüşülmüş ve oteldeki çalışan sayıları sorulmuştur. Çalışma Kasım ayında yapılması nedeniyle ilçedeki devamlı açık olan otellerdeki personel sayısı da, yüksek sezondan düşüktür. Bu durum çalışma evrenini daraltmıştır. Çalışmanın sezon sonunda yapılmasının temel nedeni, yüksek sezonda çalışanların yoğun iş temposu içerisinde anket doldurmaya zaman ayırmak istememeleridir.

$\mathrm{Bu}$ bilgiler 1şı̆̆ında çalışmanın yapıldığı dönemde, otellerdeki çalışanların sayısı otel yöneticileri aracılığıyla öğrenilmiştir. Buna göre ilgili otellerde çalışan sayısı 500'e yakın olarak belirlenmiştir. Evrenin belli olduğu durumda örneklem sayısını Yazıcıŏlu \& Erdoğan (2007: 72) "0,05 için Örneklem Büyüklükleri” tablosunda belirtmiştir. Bu tabloya göre 500 kişiye kadar örneklem sayısı 217'dir. Her ne kadar otellere 300'e yakın anket birakıldıysa da, bunların 232'si doldurulmuş (77\% geri dönüş oranı), ancak bu anketlerin de 14'ü tamamlanmamıştır. Bu nedenle değerlendirmeye toplamda 218 anket alınmıştır. Çalışma içerisinde belirlenen hipotezlerin analizinde korelasyon ve çoklu regresyon analizlerinden yararlanılmıştır.

\section{BULGULAR}

Çalışmada elde edilen veriler doğrultusunda değişkenler arasındaki ilişkilerin ortaya konulmasında korelasyon analizinden yararlanılmıştır. Korelasyon analizine yönelik veriler Çizelge 1'de gösterilmiştir.

Çizelge 1: Örgütsel adalet, örgütsel sinizm ve işten ayrılma niyeti arasındaki ilişkiye yönelik korelasyon analizi

\begin{tabular}{|c|c|c|c|c|c|c|c|c|c|c|}
\hline & & $\begin{array}{l}\text { Art. } \\
\text { Ort. }\end{array}$ & Std. Sapma & 1 & 2 & 3 & 4 & 5 & 6 & 7 \\
\hline 1 & Sinizm-Duygusal & 2,61 & 1,16127 & 1 & & & & & & \\
\hline 2 & Sinizm-Davranış & 3,71 & 1,15162 &, $153^{*}$ & 1 & & & & & \\
\hline 3 & Genel Sinizm & 2,98 &, 84390 &, $783 * *$ &, $640 * *$ & 1 & & & & \\
\hline 4 & Dağıtım Adaleti & 2,85 & 1,18007 &,$- 296 * *$ &,$- 298 * *$ &,$- 380 * *$ & 1 & & & \\
\hline 5 & İşlemsel Adalet & 3,25 & 1,27294 &,- 036 &, $269 * *$ & 081 &, $219 * *$ & 1 & & \\
\hline 6 & Etkileşim Adaleti & 3,47 & ,95419 &,$- 221 * *$ &,- 037 &,$- 215^{* *}$ &, $543 * *$ &, $688^{* *}$ & 1 & \\
\hline 7 & Genel Adalet AlgıSı & 3,28 & ,87719 &,$- 219 * *$ &,- 065 &,$- 232 * *$ &, $716^{* *}$ &, $708^{* *}$ &, $943^{* *}$ & 1 \\
\hline 8 & İşten Ayrılma Niyeti & 3,09 & 1,70795 &, $285^{* *}$ &,$- 257^{* *}$ &, $175^{* *}$ &,- 095 &,$- 210^{* *}$ &,- 110 &,$- 172 *$ \\
\hline
\end{tabular}

$* \mathrm{p}<.005 ; * * \mathrm{p}<.001$

Korelasyon analizi sonucunda değişkenler arasında istatistik açıdan anlamlı ilişkiler çıkmıştır. Literatürdeki örgütsel adalet ile örgütsel sinizm arasındaki ters yönlü ilişki, mevcut çalışmada da desteklenmiştir $(\mathrm{r}=-, 232 ; \mathrm{p}<.001)$. Diğer yandan örgütsel sinizm ile işten ayrılma niyeti arasında pozitif $(\mathrm{r}=, 175$; $\mathrm{p}<.001$ ); buna karşın örgütsel adalet ile işten ayrılma niyeti arasında negatif yönlü ilişki saptanmıştır ( $\mathrm{r}=-, 172 ; \mathrm{p}<.005)$. Örgütsel sinizm ve örgütsel adalet kavramlarının boyutları ile işten ayrılma niyeti arasında da istatistik açıdan anlamlı sonuçlar elde edilmiştir. Buna göre dağıtım adaleti duygusal $(\mathrm{r}=-, 296 ; \mathrm{p}<.001)$ ve davranışsal sinizm $(\mathrm{r}=-, 298 ; \mathrm{p}<.001)$ ile negatif yönlü; işlemsel adalet sadece davranışsal sinizm $(\mathrm{r}=, 269 ; \mathrm{p}<.001)$ ile ve pozitif yönlü; etkileşim adaleti de sadece duygusal sinizm $(\mathrm{r}=-, 221 ; \mathrm{p}<.001)$ ile negatif yönlü ilişkilidir. İșten ayrılma niyeti ise sadece işlemsel adalet ile negatif yönlü ilişkilidir $(r=-, 210 ; \mathrm{p}<.001)$.

Bağımlı ve bağımsız değișkenler arasındaki ilișkiyi açıklayan regresyon analizi (Kalaycı,2005:259), mevcut çalışmada örgütsel adalet algısının ve boyutlarının örgütsel sinizm ve boyutları ile ișten ayrılma niyetine etkilerini açıklamak üzere kullanılmıştır. Bu anlamda iki veya daha fazla açıklayıcı değişkenin olması nedeniyle çalışmada çoklu regresyon analizi yapılmıștır. Regresyon analizine yönelik veriler Çizelge 2' de gösterilmektedir.

Çalışmada örgütsel adaletin örgütsel sinizme negatif etkisine yönelik olan ilk hipotez desteklenmiștir ( $\beta=-, 232$; $\mathrm{p}<.001)$. Örgütsel adalet algısının boyutlarından dağıtım adaleti, sinizmin duygusal $(\beta=-, 215 ; \mathrm{p}<.001)$ ve davranış boyutlarını $(\beta=-, 290 ; \mathrm{p}<.001)$ negatif yönde etkilemektedir. $\mathrm{Bu}$ anlamda $\mathrm{H}_{1 \mathrm{~b}}$ kısmen desteklenmiştir. İşlemsel adalet örgütsel sinizmi davranış boyutu ile pozitif yönde etkilemektedir $(\beta=, 475 ; p<.001)$. Buna göre $\mathrm{H}_{1 \mathrm{c}}$ desteklenmemiştir. Etkileşim adaleti ise duygusal sinizmi $(\beta=-, 212 ; p<.001)$ ve davranış sinizmini $(\beta=-, 206 ; p<.001)$ negatif yönde etkilemektedir. $H_{1 d}$ ise kısmen desteklenmiştir.

Çizelge 2: Değişkenlerarası çoklu regresyon analizi

\begin{tabular}{lllllllll}
\multirow{2}{*}{ Bağımı Değişken } & Bağımsız Değişken & $\beta$ & B & $\begin{array}{c}\text { Std. } \\
\text { Hata }\end{array}$ & t & $\mathbf{R}^{2}$ & $\Delta \mathbf{R}^{2}$ & $\mathbf{F}$ \\
\hline
\end{tabular}


B. GÜZEL, G. AYAZLAR / KMÜ Sosyal ve Ekonomik Araştırmalar Dergisi 16 (26): 133-142, 2014

\begin{tabular}{|c|c|c|c|c|c|c|c|c|}
\hline \multicolumn{9}{|l|}{ Örgütsel Sinizm } \\
\hline & Örgütsel Adalet Algısı &,$- 232^{*}$ &,- 223 &, 064 & $-3,500$ & 054 & 049, & $12,250^{*}$ \\
\hline \multicolumn{9}{|c|}{ Isşten Ayrllma Niyeti } \\
\hline & Genel Adalet Algisı &,$- 172^{*}$ &,- 334 &, 131 & $-2,562$ & 029 & 025 & $6,563^{*}$ \\
\hline \multicolumn{9}{|l|}{ Sinizm-Duygusal } \\
\hline & Dağıtım Adaleti &,$- 215^{*}$ &,- 211 &, 078 & $-2,699$ & \multirow{3}{*}{, 105} & \multirow{3}{*}{, 092} & \multirow{3}{*}{$8,343^{*}$} \\
\hline & İşlemsel Adalet &, 157 &, 143 &, 084 & 1,705 & & & \\
\hline & Etkileşim Adaleti &,$- 212 *$ &,- 258 &, 130 & $-1,981$ & & & \\
\hline \multicolumn{9}{|l|}{ Sinizm-Davranış } \\
\hline & Dağıtım Adaleti &,$- 290^{*}$ &,- 283 &, 072 & $-3,913$ & \multirow{3}{*}{, 222} & \multirow{3}{*}{, 211} & \multirow{3}{*}{$20,356^{*}$} \\
\hline & İşlemsel Adalet &, $475^{*}$ & ,429 &, 078 & 5,525 & & & \\
\hline & Etkileşim Adaleti &,$- 206^{*}$ &,- 249 &, 120 & $-2,063$ & & & \\
\hline \multicolumn{9}{|c|}{ İşten Ayrlma Niyeti } \\
\hline & Dağıtım Adaleti &,- 113 &,- 164 &, 118 & $-1,384$ & \multirow{3}{*}{, 055} & \multirow{3}{*}{, 042} & \multirow{3}{*}{$4,151^{*}$} \\
\hline & İşlemsel Adalet &,$- 289 *$ &,- 388 &, 127 & $-3,056$ & & & \\
\hline & Etkileşim Adaleti &, 151 & ,270 & ,197 & 1,373 & & & \\
\hline
\end{tabular}

Çalışmanın diğer hipotezi ise örgütsel adalet algılarının işten ayrılma niyetine negatif etkisidir. Genel adalet algısının işten ayrılma niyetini negatif etkilediği saptanmıştır ( $\beta=-, 172$; $\mathrm{p}<.001)$. $\mathrm{Bu}$ durumda $\mathrm{H}_{3 \mathrm{a}}$ desteklenmiştir. Adalet algıları kapsamında sadece işlemsel adalet işten ayrılma niyetini negatif yönde etkilemiştir $(\beta=-, 289 ; \mathrm{p}<.001)$. Dolayısılla, $\mathrm{H}_{3 \mathrm{~b}} \mathrm{k}$ ksmen desteklenmiştir.

\section{Tartısma ve Sonuc}

$\mathrm{Bu}$ çalışmanın amacı, otel işletmelerinde çalışanların örgütsel adalet algılarının, sinik tutumlarına ve işten ayrılma niyetine etkileri ile, sinik tutumlarının da işten ayrılma niyetine etkilerinin ortaya konulmasıdır. Çalışma kavramlar arasındaki doğrudan ilişkinin ortaya konulması noktasında önemlidir.

Çalışmanın bulguları literatür ile değerlendirildiğinde, örgütsel adaletin işten ayrılma niyeti ile arasındaki doğrudan ilişki önemlidir. Örgütsel adalet algısı her ne kadar işten ayrılma niyeti ile ilişkili olsa da, adalet boyutlarından sadece işlemsel adalet ile açıklanmaktadır. $\mathrm{Bu}$ noktada elde edilen bulgu, Colquitt vd. (2001) ile Özer \& Günlük (2010) çalışmasından farklıdır. Kaldı ki bulgu, Nadiri \& Tanova (2010)'un çalışmasının aksi sonuç vermiştir. Mevcut çalışmadaki bulgunun, örgütsel adalet kavramını örgütsel bağlılık ile ilişkilendiren Folger ve Konovsky (1989) doğrultusunda olduğu düşünülebilir. Zira örgütsel bağlılığın düşük olmasının işten ayrılma niyetinde artışa neden olduğu göz önüne alınmalıdır (Tayfun vd., 2008: 8). Bu anlamda mevcut çalışmada işlemsel adaletin açıklayıcı olması, yapılan uygulamalarda süreçlerin çalışanların işten ayrılma niyeti göstermelerindeki önemini ortaya koymaktadır. Her ne kadar çalışan, sosyal değişim kapsamında kendini örgüte bağlı olmaya zorunlu hissetse de (Cohen-Charash ve Spector, 2001: 306), çalışanlara söz hakkının verilmesi, hataların düzeltilmesi olanağının sunulması ve alınan kararlarda uygulanan süreçlerin adil olduğu algısının yerleştirilmesi sayesinde çalışanlarda örgüte bağlılık daha yüksek olabilecektir.

Örgütsel adalet ve örgütsel sinizm arasındaki mevcut çalışmadaki ilişki, literatür ile benzer sonuçları taşımaktadır (Bernerth vd., 2007; James, 2005; Bateman, 1992). Buna göre örgüt içerisindeki adaletsizlik algısı, çalışanlarda sinik tutumların da artmasına neden olmaktadır. Kavramlar boyutlar kapsamında incelendiğinde ise sinizmin duygusal boyutunu sadece dağıtım ve etkileşim adaletinin etkilediği ve negatif yönlü; sinizmin davranış boyutunu ise dağıtım ve etkileşim adaletinin negatif yönlü, işlemsel adaletin ise pozitif yönlü etkilediği saptanmıştır. Boyutların birbirini etkilemesine yönelik elde edilen bulgular literatür ile farklılık göstermektedir ki bunun temel nedeni, çalışmalarda hipotezlerin birbirlerinden farklı şekilde kurulmuş olmasıdır. Örneğin Bernerth vd. (2002), ve Fitzgerald (2002) adalet boyutlarını örgütsel sinizme etkisine yönelik çalışırken, mevcut çalışma örgütsel sinizmi boyutları ile birlikte değerlendirmiştir. $\mathrm{Bu}$ anlamda Efeoğlu ve İplik (2011) ile benzer yöndedir. Efeoğlu ve İplik (2011) dağıtım ve işlemsel adaletin duygusal adaleti; kişilerarası ve bilgi adaletinin ise duygusal adaleti açıkladığını belirtmiştir. Farklı sonuçlardaki çalışmada duygusal sinizmde dağıtım adaletinin daha baskın olduğunu söylemek mümkündür. $\mathrm{Bu}$ anlamda kaynakların adil dağıtımlarının, örgüte yönelik duyguları olumlu etkilediği, aynı zamanda kişilerarası ilişkilerin, çalışanlara verilen değerin de olumsuz duyguları azalttığı söylenebilir. Benzer durum sinizmin davranıș boyutu için de geçerli olsa da, işlemsel adalet sağlanması durumunda bile, çalışanların sinik davranışlarında artış olabilmektedir. Bu anlamda örgüt kaynak dağıtımındaki süreçleri adil olarak tanımlamasına rağmen, çalışanlar diğer çalışanlar ile örgüt uygulama ve politikalarını konuşmakta, eleştirmekte ve kendi aralarında birtakım bakışmalar ile olumsuz duygularını ifade etmektedir. Elde edilen bulgular değerlendirilirken dikkat edilmesi gereken konu, belli bir düzeyde adaletsizlik algısının kaçınılmaz olduğu (Greenberg, 2004: 359) ve insanların nesnel gerçekler yerine algılara göre tepki verdikleridir (Greenberg, 2011: 67).

Çalışma yazında gelecek çalışmalar için yol gösterici bir rehber olarak düşünülmelidir. Zira kavramlar arasındaki doğrudan ilişkilerin incelenmiş olması önemlidir. Ancak çalışmanın farklı sektörlerde ve dönemlerde de yapılması, bulguların geçerliliğini etkileyebilecektir. Kaldı ki çalışmanın turizm bölgelerinden sadece belli bir destinasyondaki belli 
yıldız sayısına sahip otel işletmelerinde yapılmış olması da önemli bir kısıt olarak düşünülmelidir. Bunlarla beraber, kavramlar arasındaki doğrudan ilişkilerde farklı değişkenlerin de etkisini incelemek gerekmektedir. Zira örgütsel sinizm kavramını etkileyebilecek ve örgütsel adalet algısının farklı çıktılarına neden olabilecek başka değişkenlerin olması mümkündür. Aynı zamanda örgütsel sinizmin işten ayrılma niyetine etkisinde örgütsel adalet algısının aracılık etkisinin incelenmesi, örgütsel sinizmin mi işten ayrılma niyetine etkisinin olduğu veya işten ayrılma niyeti sonucunda mı kişilerde sinik tutumların meydana geldiği sorularının da cevaplarının aranması önerilmektedir.

\section{KAYNAKLAR}

Abraham, R. (2000). Organizational Cynicism Bases and Consequences. Genetic, Social and General Psychology Monographs, 126 (3), 269-292.

Allen, D. G., Shore, L. M., Griffeth, R. W. (2003). The Role of Perceived Organizational Support and Supportive Human Resource Practices in the Turnover Process. Journal of Management, 29 (1), 99-118.

Andersson, L.M. (1996). Employee Cynicism: An Examination Using a Contract Violation Minority Framework. Human Relations, 49 (11), 1395-1417.

Aryee, S., Chen, Z. X. \& Budhwar, P. S. (2004). Exchange Fairness and Employee Performance: An Examination of the Relationship Between Organizational Politics and Procedural Justice. Orgnaizational Behavior and Human Decision Processes, 94, 1-14.

Bateman, T.S., Sakano, T. \& Fujita, M. (1992). Roger, me, and my attitude: Film propaganda and cynicism toward corporate leadership. Journal of Applied Psychology, 77(5), 768-771.

Bedeian, A. (2007). Even If The Tower is 'Ivory', It Isn't White: Understanding The Consequences of Faculty Cynicism. Academy of Management Learning \& Education, 6(1), 9-32.

Bernerth, J. B., Armenakis, A. A., Feild, H. S., \& Walker, J. (2007). Justice, cynicism, and commitment: A study of important organizational change variables. Journal of Applied Behavioral Science, 43(3), 303-326.

Blakely, G. L., Andrews, M. C. \& Moorman, R. H. (2005). The Moderating Effects of Equity Sensitivity on the Relationsgip Between Organizational Justice and Organizational Citizenship Behaviors. Journal of Business and Psychology, 20 (2), 259273.

Blau, G. (2007). Does a Corresponding Set of Variables for Explaining Voluntary Organizational Turnover Transfer to
Explaining Voluntary Occupational Turnover?. Journal of Vocational Behavior, 70, 135-148.

Bridges, E., Johnston, H. H. \& Sager, J. K. (2007). Using Model-Based Expectations to Predict Voluntary Turnover. International Journal of Research in Marketing, 24, 65-76.

Brown, S., Garino, G. \& Martin, C. (2009). Firm Performance and Labour Turnover: Evidence From The 2004 Workplace Employee Relations Survey. Economic Modelling, 26, 689-695.

Chan, E-Y. \& Morrison, P. (2000). Factors Influencing the Retention and Turnover Intentions of Registered Nurses in a Singapore Hospital. Nursing and Health Sciences, 2, 113-121.

Chen, C-F. (2006). Job Satisfaction, Organizational Commitment, and Flight Attendants' Turnover Intentions: A Note. Journal of Air Transport Management, 12, 274-276.

Cho, S., Woods, R. H., Jang, S. \& Erdem, M. (2009). Measuring the Impact of Human Resource Management Practices on Hospitality Firms' Performances. Hospitality Management, 25, 262-277.

Cohen-Charash, Y. \& Spector, P. E. (2001). The Role of Justice in Organizations: A Meta Analysis, Organizational Behavior and Human Decision Processes, 86(2), 278-321.

Colquitt, J. A. (2001). On the Dimensionality of Organizational Justice: A Construct Validation of a Measure. Journal of Applied Psychology, 86 (3), 386-400.

Colquitt, J. A. (2009). Two Decades of Organizational Justice: Findings, Controversies, and Future Directions, in Barling, J. \& Cooper, C. L. (Edts.) The SAGE Handbook of Organizational Behavior, USA: Sage Publication.

Colquitt, J. A., Conlon, D. E., Wesson, M. J., Porter, C. O. L. H. \& Ng, K. Y. (2001). Justice at the Millenium: A MetaAnalytic Review of 25 Years of Organizational Justice Research. Journal of Applied Psychology, 86 (3), 425-445.

Conklin, M. H. \& Desselle, S. P. (2007). Job Turnover Intentions Among Pharmacy Faculty. American Journal of Pharmaceutial Education, 71 (4), 1-9.

Coomber, B. \& Barriball, K. L. (2007). Impact of Job Satisfaction Components on Intent to Leave and Turnover For Hospital-Based Nurses: A Review of the Research Literature. International Journal of Nursing Studies, 44, 297-314.

Cordes, C. L. \& Dougherty, T. W. (1993). A Review And An Integration of Research in Job Burnout. Academy of Management Review , 18, 621-656.

Cropanzano, R. \& Mitchell, M. S. (2005). Social Exchange Theory: An Interdisciplinary Review. Journal of Management, 31 (6), 874-900. 
Dean Jr., J. W., Brandes, P. \& Dharwadkar, R. (1998). Organizational Cynicism. Academy of Management Reviews, 23 (2), 341-352.

DeConinck, J. B. (2010). The Effect of Organizational Justice, Perceived Organizational Support, And Perceived Supervisor Support on Marketing Employees' Level of Trust. Journal of Business Research, 63, 1349-1355.

Ducharme, L. J., Knudsen, H. K. \& Roman, P. M. (2008). Emotional Exhaustion and Turnover Intention in Human Service Occupations: The Protective Role of Coworker Support. Sociological Spectrum, 28 (8), 81-104.

Efeoğlu, İ. E. \& İplik, E. (2011). Algılanan Örgütsel Adaletin Örgütsel Sinizm Üzerindeki Etkilerini Belirlemeye Yönelik İlaç Sektöründe Bir Uygulama. Çukurova Üniversitesi Sosyal Bilimler Enstitüsü Dergisi, 20(3), 343-360.

Fitzgerald, M. (2002). Organizational Cynicism: Its Relationship Perceived Organizational Injustice Explanatory Style, A Dissertation Presented to The Division of Research and Advanced Studies of University of Cincinnati.

Folger, R. \& Konovsky, M. A. (1989). Effects of Procedural and Distributive Justice on Reactions to Pay Raise Decisions, The Academy of Management Journal, 32(1), 115-130.

Gegez, A. E. (2010). Pazarlama Araştırmaları. 3. Bask1. İstanbul: Beta Basım Yayım Dağıtım A.Ş.

George, J. M. \& Jones, G. R. (2008). Understanding and Managing Organizational Behavior, Fifth Edition, USA: Pearson Prentice Hall.

Geurts, S. A. Schaufeli, W. B. \& Rutte, C. G. (1999). Absenteeism, Turnover Intention and Inequity in the Employment Relationship. Work \& Stress, 13 (3), 253-267.

Gilliland, S. (2008). The Tails of Justice: A Critical Examinaiton of the Dimensionality of Organizational Justice Constructs. Human Resource Management Review, 18, 271281.

Greenberg, J. \& Baron, R. A. (2003). Behavior in Organizations, Understanding and Managing the Human Side of Work (8th Edition), USA: Prentice Hall.

Greenberg, J. (1990). Organizational Justice. Yesterday, Today and Tomorrow. Journal of Management, 16(2), 399-432.

Greenberg, J. (2004). Stress Fairness to Fare No Stress: Managing Workplace Stress by Promoting Organizational Justice. Organizational Dynamics, 33 (4), 352-365.

Greenberg, J. (2011). Behavior in Organizations (10th Edition), USA: Pearson.
Hammerberg, H. J. (2002) Reasons Given For Employee Turnover in a Full Price Department Store, The Graduate School University of Wisconsin-Stout: Menomonie.

Herda, D. N. \& Lavelle, J. J. (2012). The Auditor-Audit Firm Relationship and Its Effect on Burnout and Turnover Intention. Accounting Horizons, 26 (4), 707-723.

Hochwarter, W., James, M., Johnson, D. \& Ferris, G. (2004). The Interactive Effects of Politics Perceptions And Trait Cynicism On Work Outcomes. Journal of Leadership And Organizational Studies, 10, 44-58.

Hom, P. W., Caranikas W., F., Prussia, G. E. \& Griffeth, R. W. (1992). A Meta-Analytical Structural Equations Analysis of a Model of Employee Turnover, Journal of Applied Psychology, 78, 890-909.

Hsu, M. K., Jiang, J. J., Klein, G. \& Tang, Z. (2003). Perceived Career Incentives and Intent to Leave. Information \& Management, 40, 361-369.

James, M. S. L. (2005). Antecedents And Consequences of Cynicism in Organizations: An Examination of The Potential Positive And Negative Effects on School Systems. A Dissertation Presented to The College of Business, The Florida State University, USA.

Jang, J. \& George, R. T. (2012). Understanding the Influence of Polychronicity on Job Satisfaciton and Turnover Intention: A Study of Non-Supervisory Hotel Employees. International Journal of Hospitality Management,31, 588-595.

Johnson, J. \& O'Leary-Kelly, A. M. (2003). The Effects of Psychological Contract Breach And Organizational Cynicism: Not All Social Exchange Violations Are Created Equal. Journal of Organizational Behavior, 24 (5), 627-647.

Kağıtçıbaş1, Ç. (2010). Günümüzde Insan ve Insanlar, Sosyal Psikolojiye Giriş, 12. Basım, İstanbul: Evrim Yayınevi ve Bilg. San. Tic. Ltd. Şti.

Kalaycı, Ş. (2005). SPSS Uygulamalı Çok Değişkenli İstatistik Teknikleri, Ankara: Asil Yayın Dağıtım.

Kanter, D. L., \& Mirvis, P. H. (1991). Cynicism: The new American malaise. Business \& Society Review, 91 (77), 57-61.

Karatepe, O. M. \& Aleshinloye, K. D. (2009). Emotional Dissonance and Emotional Exhaustion Among Hotel Employees in Nigeria. International Journal of Hospitality Management, 28, 349-358.

Karriker, J. H. \& Williams, M. L. (2009). Organizational Justice and Organizational Citizenship Behavior: A Mediated Multifoci Model, Journal of Management, 35(1), 112-135.

Kelly, C. \& Kelly, J. (1991). Them And Us: Social Psychology And The New Industrial Relations, British Journal of Industrial Relations, 29, 25-48. 
B. GÜZEL, G. AYAZLAR / KMÜ Sosyal ve Ekonomik Araştırmalar Dergisi 16 (26): 133-142, 2014

Kim, T.-Y. \& Leung, K. (2007). Forming and Reacting to Overall Fairness: A Cross-Cultural Comparison. Organizational Behavior and Human Decision Processes, 104, 83-95.

Kitchin, P. D. (2010). An Introduction to Organizational Behaviour for Managemers and Engineers, A Group and Multi Cultural Approach. USA: Butterworth Heinemann.

Korunka, C., Hoonakker, P. \& Carayon, P. (2008). Quality of Working Life and Turnover Intention in Information Technology Work. Human Factors and Ergonomics in Manufacturing, 18 (4), 409-423.

Kutanis, R. Ö. \& Çetinel, E. (2009). Adaletsizlik Algısı Sinisizmi Tetikler mi?: Bir Örnek Olay, 17. Ulusal Yönetim ve Organizasyon Kongresi Bildiriler Kitabı, 21-23 Mayıs 2009, Eskişehir, 693-699.

Lam, T., Zhang, H. \& Baum, T. (2001). An Investigation of Employees' Job Satisfaction: The Case of Hotels in Hong Kong. Tourism Management, 22, 157-165.

Lambert, W. E. (1964). Social Psychology, New Jersey: Prentice Hall.

Layne, c. M., Hohenshil, T. H. \& Singh, K. (2004). The Relationship of Occupational Stress, Psychological Strain, and Coping Resources to the Turnover Intentions of Rehabilitation Counselors. Rehabilitation Counseling Bulletin, 48 (1), 19-30.

Loi, R., Hang-Yue, N. \& Foley, S. (2006). Linking Employees' Justice Perceptions to Organizational Commitment and Intention to Leave: The Mediating Role of Perceived Organizational Support. Journal of Occupational and Organizational Psychology, 79, 101-120.

Mahdi, A. F., Zin, M. Z.M., Nor, M. R. M., Sakat, A. A. \& Naim, A. S. A. (2012). The Relationship Between Job Satisfaction and Turnover Intention. American Journal of Applied Sciences, 9 (9), 1518-1526.

Masterson, S. S., Lewis, K., Goldman, B. M. \& Taylor, M. S. (2000). Integrating justice and social exchange: The differing effects of fair procedures and treatment on work relationships, Academy of Management Journal, 43, 738-748.

Mitchell, J. I., Gagné, M., Beaudry, A. \& Dyer, L. (2012). The Role of Perceived Organizational Support, Distributive Justice and Motivation in Reactions to New Information Technology. Computers in Human Behavior, 28, 729-738.

Morrison, R. (2004). Informal Relationships in the Workplace: Associations With Job Satisfaction, Organizational Commitment and Turnover Intentions, New Zealand Journal of Psychology, 33 (3), 114-128.

Nadiri, H. \& Tanova, C. (2010). An Investigation of the Role of Justice in Turnover Intentions, Job Satisfaction, and
Organizational Citizenship Behavior in Hospitality Industry, International Journal of Hospitality Management, 29, 33-41.

Naus, F., Van Iterson, A. \& Roe, R. (2007). Organizational cynicism: extending the exit, voice, loyalty and neglect model of employees' response to adverse conditions in the workplace. Human Relations, 60, 683-718.

Niehoff, B. P. \& Moorman, R. H. (1993). Justice as a Mediator of the Relationship between Methods of Monitoring and Organizational Citizenship Behavior. The Academy of Management Journal, 36 (3), 527-556.

Ohana, M. \& Meyer, M. (2010). Should I Stay or Should I Go Now? Investigating the Intention to Quit of the Permanent Staff in Social Enterprises. European Management Journal, 28, 441454.

O’Neill, J. W. \& Davis, K. (2011). Work Stress and WellBeing in the Hotel Industry. International Journal of Hospitality Management, 30, 385-390.

O'Leary, M. (2003). From paternalism to cynicism: Narratives of a newspaper company, Human Relations, 56 (6), 685-704.

Onay, M. \& Kılc1, S. (2011). İş Stresi ve Tükenmişlik Duygusunun İşten Ayrılma Niyeti Üzerine Etkileri: Garsonlar ve Aşçıbaşılar. Organizasyon ve Yönetim Bilimleri Dergisi, 3 (2), 363-372.

Özer, G. \& Günlük, M. (2010). Örgütsel Adaletin Muhasebecilerin İş Memnuniyeti ve İşten Ayrılma Niyetine Etkisi, Gaziantep Üniversitesi Sosyal Bilimler Dergisi, 9(2), 459-485.

Patel, C., Budhwar, P. \& Varma, A. (2012). Overall Justice, Work Group Identification and Work Outcomes: Test of Moderated Mediation Process. Journal of World Business, 47, 213-222.

Rehman, M. S. (2012).Employee Turnover and Retention Strategies: An Empirical Study of Public Sector Organizations of Pakistan. Global Journal of Management and Business Research, 12 (1), 83-89.

Reichers, A.E., Wanous, J.P. \& Austin, J.T. (1997). Understanding And Managing Cynicism About Organizational Change. Academy of Management Executive, 11(1), 48-59.

Rosin, H. \& Korabik, K. (1995). Organizational Experiences and Propensity to Leave: A Multivariate Investigation of Men and Women Managers. Journal of Vocational Behavior, 46, 116 .

Sarıdede, U. \& Doyuran, Ş. (2004). Eğitim örgütlerinde Örgütsel Bağlılığın İşten Ayrılma Niyetine Etkisi, XIII. Ulusal Ĕ̌itim Bilimleri Kurultayl, 6-9 Temmuz, İnönü Üniversitesi, Eğitim Fakültesi, Malatya. 
B. GÜZEL, G. AYAZLAR / KMÜ Sosyal ve Ekonomik Araştırmalar Dergisi 16 (26): 133-142, 2014

Shaw, J. D. (1999). Job Satisfaction and Turnover Intentions: The Moderating Role of Positive Affect. The Journal of Social Psychology, 139 (2), 242-244.

Şimşek, Ş., Akgemci, T. \& Çelik, A. (2005). Davranış Bilimlerine Giriş ve Örgütlerde Davranış, Yenilenmiş Dördüncü Baskı, Adım Matbaacılık: Konya.

Singh, J., Verbeke, W. ve Rhoads, G. K. (1996). "Do Organizational Practices Matter in Role Stress Processes? A Study of Direct and Moderating Effects for Marketing-Oriented Boundary Spanners", Journal of Marketing, 60: 69-86.

Stroh, L. K., Northcraft, G. B. \& Neale, M. A. (2002). Organizational Behavior, A Management Challenge, 3rd Edition, USA: Lawrence Erlbaum Associates, Publishers.

Tayfun, A., Palavar, K. \& Yazıcıoğlu, İ. (2008). Otel İşletmelerinde Çalışan İşgörenlerin Örgütsel Bağlılık Düzeylerinin Çeşitli Değişkenlere Göre İncelenmesi. Kamu-Işs Dergisi, 9(4), 1-22.

Toker, B. (2007). Demografik Değişkenlerin İş Tatminine Etkileri İzmir'deki Beş ve Dört Yıldızlı Otellere Yönelik Bir Uygulama, Doğuş Üniversitesi Dergisi, 8 (1), 92-107.

Trevor, C. O. (2001). Interactions Among Actual Ease-OfMovement Determinants and Job Satisfaction in the Prediction of Voluntary Turnover, Academy of Management Journal, 44 (4), 621-638.

Tzeng, H. M. (2002). The Influence of Nurses' Working Motivation and Job Satisfacton on Intention to Quit: An Empirical Investigation in Taiwan. International Journal of Nursing Studies, 39, 867-878.

Ucho, A., Mkavga, T. \& Onyishi, I. E. (2012). Job Satisfaction, Gender, Tenure, and Turnover Intentions Among Civil Servants in Benue State. Interdisciplinary Journal of Contemporary Research in Business, 3 (11), 378-387.

Williams, S., Pitre, R. \& Zainuba, M. (2002). Justice and Organizational Citizenship Behaivor Intentions: Fair Rewards Versus Fair Treatment. The Journal of Social Psychology, 142 (1), 33-44.

Yazıcıŏlu, Y. \& Erdoğan, S. (2007). SPSS Uygulamalı Bilimsel Araştırma Yöntemleri, Genişletilmiş 2. Baskı, Ankara: Detay Yayinevi.

Yildiz vd., (2009). The Impact of Nurses' Motivation to Work, Job Satisfaction, And Sociodemographic Characteristics on Intention to Quit Their Current Job: An Empirical Study in Turkey. Applied Nursing Research, 22, 113-118.

You, Y. J. (1992). An Empirical Test of Turnover Theory: In the Case of Korean Hotel Employees. Asia Pacific Journal of Tourism Research, 1(1), 50-60. www.aydinkulturturizm.gov.tr, 31.10 .2012 Tarihi İtibariyle İşletme Belgeli Tesisler. 